\title{
Corporate Groups under the Laws of Rwanda: An Economic Reality without Legal Identity
}

\author{
Dieudonné Nzafashwanayo* \\ ENSafrica, Kigali, Rwanda \\ Email: dnzafashwanayo@gmail.com,dnzafashwanayo@ensafrica.com
}

Received 4 April 2016; accepted 9 May 2016; published 12 May 2016

Copyright (C) 2016 by author and Scientific Research Publishing Inc. This work is licensed under the Creative Commons Attribution International License (CC BY). http://creativecommons.org/licenses/by/4.0/ (c) (i) Open Access

\section{Abstract}

Corporate groups have become common in and dominate the business world. They emerge from reconfiguration of large companies into a multitude of subsidiaries from the simplest radial structure to the complex pyramidal and circular structures, in all structures, all companies within the group being ultimately held by a single parent company. Despite the omnipresence of corporate groups and their place in business world, their legal nature is yet to be seen whereas the use of this structure (corporate groups) to conduct business leads to tensions with traditional corporate law notions of each company being a separate legal entity and the blurring of lines of independence and modus operandi of corporate groups can be dangerous for creditors, employees, minority shareholders and pose challenges for regulators (such as taxman and anti-trust regulatory bodies) assessing the status of transactions conducted within the group. This article will discuss the notion of corporate groups under the laws of Rwanda and will argue that, albeit the fact that corporate groups (under traditional principles of corporate law) do not have legal existence, in some branches of law such as tax, anti-trust, employment, banking and finance law, the same have got a legal recognition and are treated as such. However, it will be submitted that the tenor of and challenges posed by corporate groups call for a clear recognition and stand of the legislator on the legal nature of corporate groups.

\section{Keywords}

Corporate Group, Legal Entity, Economic Interdependence, Control

\footnotetext{
*Dieudonné Nzafashwanayo is a practicing advocate of the High Court of Rwanda, working as an associate with ENSafrica where he specializes in labor and employment law, corporate law, contract law, property and security law, anti-trust and consumer protection law as well as banking and finance law. His practical experience includes advising on employment arrangements, Rwandan foreign entry modes, energy projects, Employee Stock Ownership Plans (ESOPs) and their tax treatment, undertaking due diligence in asset/stock deals and credit lines extension transactions. He holds an LLB with First Class Honors (University of Rwanda).
} 


\section{Introduction}

Today, the business is becoming ever more global in reach, with cross-border business becoming a norm and the role played by corporate groups is critical. As Phillip Blumberg, the leading author on corporate groups, has observed, corporate groups of enormous size with complex multi-tiered corporate structures dominate the national and world economy (Blumberg, 2005). In Rwandan context, the existence of corporate group is beyond any dispute, as currently company members of large groups, such as MTN Group ${ }^{1}$, Engen Petroleum ${ }^{2}$ and Bharti Airtel $^{3}$ to mention but three, have presence in Rwanda. This has been spurred by the Rwandan Companies Act, albeit it does not refer to corporate groups in se, but the fact that it does allow companies to hold the majority shareholding in other companies, even on a hundred per cent basis makes the expansion of various companies to form multi-tiered corporate groups through incorporation of subsidiaries/wholly owned subsidiaries an inevitable economic reality.

However, the increased expansion of companies to form corporate groups has not gone hand in hand with the development of legal landscape to accommodate them, and much like other jurisdictions Rwanda is not spared from the legal void surrounding corporate groups. The controversy surrounding the legal regime of corporate groups was recognized by (Estrabaud, 2014) in his book entitled Les Groupes de Sociétés en Droit de la Concurrence et en Droit Fiscal where he describes it as follows in French:

Le phénomène des groupes de sociétés, archétype parfait de la confrontation du droit au fait, passionne la doctrine juridique. L'opposition frappante entre l'importance économique des groupes et la timide action du législateur, dont le juge s'efforce de combler les silences, est un terreau idéal pour la réflexion juridique, ainsi qu'en témoignent les nombreuses thèses ou articles qui y sont consacrés. Cette opposition est d'autant plus renforcée que chaque branche du droit concernée par ce phénomène avance à son propre rythme dans la prise en compte des groupes. Le Professeur Le Gall et Me Coudin avaient anticipé cet état dans un commentaire de l'article 68 de loi de finances pour 1984: "Ledroit des groupes de sociétés, aujourd'hui encore embryonnaire, sera conduit à s'organiser et se composer autour d'un tronc commun sur lequel viendront se greffer un nombre variables de branches". Si il n'est pas certain qu'en 2014 le droit des groupes de sociétés a dépassé le stade embryonnaire, ni qu'un tronc commun puisse réellement se détacher, il est en revanche certain que de nombreuses branches du droit ont développé, de manière indépendante, un corpus juridique complexe concernant les groupes de sociétés. Ce système complexe est joliment résumé par la formule suivante: "la notion de groupe de sociétés est un prisme qui reflète une image différente selon la facette du droit qui est observée"4.

From the above, it is obvious that the legal regime of corporate groups remains to be a moot point, despite the fact that corporate groups result from an ancient economic phenomenon whose importance has become much more significant in economy of the $21^{\text {st }}$ century. Moreover, the lack of a clear legal regime of them should not be taken to be innocuous since being an existing economic reality, within groups, are various uncommendable transactions, that are in some instances condemned by regulators in various jurisdictions (European Commission, $2015)^{5}$ and groups' structural organization and centralized management pose specific dangers for creditors when

${ }^{1}$ MTN Group is a South Africabased multinational mobile telecommunications company, operating in many African, European and Asian countries.

${ }^{2}$ The company is present in over 20 countries and export products to over 30 more countries, mostly in Africa and the Indian Ocean Islands. ${ }^{3}$ Bharti Airtel Limited is an International telecommunications Services Company headquartered in New Delhi, India. It operates in 20 countries across South Asia, Africa, and the Channel Islands.

${ }^{4}$ The phenomenon of corporate group, a perfect archetype of confrontation of the law in practice, excites the legal doctrine. The stringent opposition between economic importance of corporate groups and the timid action of the legislator, of which courts endeavour to remedy the silences, is an ideal loam for the legal reflexion, as witnessed by several articles and dissertations dedicated thereon. This opposition is moreover catalysed by the fact that each branch of law concerned by that advanced phenomenon has got its own perception in consideration of corporate group. Professor Le Gall and Me Coudin have envisaged this in their commentary on article 68 of the 1984 budget law: "The law of corporate group that is today embryonic will be organized and composed around a central structure on which will be attached a number of branches". If it is not certain that in 2014 the law of corporate groups has gone beyond the embryonic stage and the central structure is yet to emerge, it is however certain that several branches of law have developed, independently, a complex corpus juris concerning corporate groups. That complex system is gladly summarized by the following formula: "the notion of corporate group is a prism that reflects different images according to the branch of law from which it is being observed”.

${ }^{5}$ For instance On October 21, 2015, the European Commission, acting as the regulator of EU competition rules, announced that it had concluded that tax rulings obtained by a Dutch subsidiary of Starbucks and a Luxembourg subsidiary of Fiat conferred illegal State aid to those companies. Further, the Commission concluded that an amount equal to the alleged tax benefits plus interest must be repaid. The alleged tax benefits were achieved through transfer pricing among company members of FIAT and STARBUCKS. 
transacting with their group member companies (Dickfos, 2011).

In this regard, it is obvious that the economic phenomenon of corporate groups is not neutral in a legal perspective, but instead poses a number of legal issues and thus call for the law to respond to this modern model of business and, therefore, this paper will find out the legal treatment of corporate groups (if at all) under the laws of Rwanda. It will define the concepts of corporate group and establish its hallmarks (2), the structuring of corporate groups (3), advantages and disadvantages associated with corporate groups (4), the legal nature of corporate groups (5), intra-group relationship (6) and ultimately the conclusion and the way forward will be offered (7).

\section{Concept and Hallmarks of Corporate Groups}

\subsection{Corporate Group Defined}

The Rwandan legislator referred to the word "corporate groups" in various pieces of legislation, but nowhere an attempt was made to have the concept defined ${ }^{6}$. However, this is not strange and not peculiar to Rwandan jurisdiction, as a number of scholars agree that the definition of the concept of corporate group is not an easy task and most of them ascribe that lack of a unanimous definition of the group to the fact that in many legal systems, corporate group is not defined. Those include Mevorach and Hmoda who put that in most of legal systems, the concept of corporate group belongs to economic sphere or that of political sciences more than it belongs to the legal sphere (Mevorach, 2009). Therefore, indeed the phenomenon of corporate groups is becoming greater in economy, be it regional or global, and it is perceived that majority of States ignore the law of corporate groups (Hmoda, 2013).

In spite of everything, doctrinal and jurisprudential efforts have undertaken to define the concept of corporate group. For instance (Vidal, 1993), has put that "the corporate group is a body of several companies presenting distinct legal entities that are linked by share participation or contractual relationship according them economic or financial interdependence which may manifest itself by the existence of the shared power of decision, external to several of those companies and proper to the body of the group". The same concept was defined by Ripert, Roblot and Germain for whom a corporate group is constituted of several companies legally independent, but which are placed in relation to one another in a state of economic dependence, susceptible to compromising their legal independence (George, René, \& Germain, 1993).

On the contrary, (Barthelemy \& Philippe, 1996) have defined the corporate group in light of the power of decision as follow: "a corporate group is a body composed of several companies each having its own legal personality, but united by various links by virtue of which one of them, called the parent company, that holds other companies under its dependence, exercises control over the body and makes prevail the unity of decision".

For (Duet, The governance of corporate groups, relationships between property and power to the test of relations of contemporary enterprise, 2007b), a corporate group can be considered as a body of companies constituted by the parent company and subsidiaries. To her, the corporate group is characterized by two main traits. First, there exits patrimonial links between entity members of the corporate group. Second, the parent company and subsidiaries are distinct legal entities and the group does not have the legal personality. She further argued that the corporate group defines itself by a system of financial links to the extent that, if the company holds the sufficient part of the share capital of another company, the former is called the parent company and the latter are called subsidiaries (Duet, The governance of corporate groups, relationships between property and power to the test of relations of contemporary enterprise, 2007b).

On his part, (Merle, 2005) estimates the corporate group to be a body of companies which, by keeping their separate legal entities, find themselves linked to one another to the extent that one of them, the parent company holds others under its dependence, in a de facto or de jure manner exercises a control over the body of dominated companies and make prevail the unity of decision.

In light of control exercised by the parent over its subsidiary, the definition of Didier is very important. He puts that a group of companies is not a body of direct subsidiaries, but also sub-subsidiaries and sister companies, which can be linked by financial or contractual relationships. It consists for that group of a body of companies

\footnotetext{
${ }^{6}$ See for instance the law $n^{0}$ 52/2008 of 10/09/2008 governing the organization of insurance business ("Insurance Business Act”) art 31 which states "Where a licensed insurer is a member of a group of companies, as defined in regulations, the licensed insurer shall submit group accounts to the Bank"; and the law n007/2008 of 08/04/2008 concerning organization of banking, ("Banking Act") art 51 which states “The Central Bank shall request any bank belonging to a group to submit its consolidated accounts".
} 
subject to the direct or indirect control, exclusive or shared by some among them, placed themselves under the control of companies situated higher in the hierarchy of the group, in its entirety dominated by a parent company, often a mere holding company belonging to a family, public domain, to the State or other groups, all mainly lying on the capital structures (Didier, 1996).

The concept of corporate group has also been defined in the jurisprudence of various courts. For instance the criminal chamber of the Cour de Cassation of France has defined the corporate group where it held that the corporate group with the commercial and financial purpose is constituted of a dominant company and other companies which closely depend on it, within the common interest, irrespective of legal form of the dominant company $^{7}$. The group must be constituted by companies that legally exists ${ }^{8}$. Recently, the court of appeal of Douai has held that the group of companies implies, on one part, the existence between its members, of crossed relationship in form of close financial relationship, privileged economic links and preferential commercial relationships and, on the other part, the control of the body, the unity of decision and a common strategy imposed by the parent company ${ }^{9}$.

\subsection{The Hallmarks of Corporate Groups}

From the foregoing doctrinal and jurisprudential definitions of the corporate group, a number of hallmarks of the corporate group can be identified and those are the existence of several companies with their separate legal entities, the existence of economic and financial dependence and the exert of control on top by the parent company. These hallmarks are discussed hereunder.

\subsubsection{The Existence of Several Companies with Their Own Separate Legal Entities}

This hallmark excludes other entities than companies enjoying or not enjoying the separate legal entities. As such, a natural person even when he/she holds the major part of the share capital of several companies cannot constitute a group $^{10}$. Further, an enterprise ${ }^{11}$ without the status of a legal entity would not be regarded to constitute a corporate group.

\subsubsection{The Existence of Economic and Financial Dependence}

Within the corporate group, the subsidiaries economically and financially depend on the parent company or other sister companies. The business activities of subsidiaries are financed by the parent company or other sister companies and, in some instances, the properties of the parent company are transferred to its subsidiaries on preferential conditions. In this respect, (Duet, Being or not being: The group as a unified enterprise or a body of companies? A sociological approach, 2007a) has put that the group forms nothing other than a single economic unity. To her, the group can be defined as a body constituted by companies that financially and economically depends on the parent that ensures control and management of dependent companies. She further put that the separate legal entity of subsidiaries is nothing other than a way of ensuring coherence of an organized body.

\subsubsection{The Exert of Control on Top by the Parent Company}

On top of the corporate group exist the parent company that exerts control over other company members of the group. This control is linked to the structure of the involved share capital and that control puts sub-subsidiaries under the control of the subsidiaries and the latter under the control of the parent company, either in form of a financial control due to the holding of the part of the share capital of subsidiaries. Exert of control may be based on direct or indirect share capital relations between the linked companies. Thus, a sister company is considered to be a member of the group even if it would be far from the parent company.

In this respect, the aforementioned definitions ascribe the control exerted on the share capital relationship whereas, although it is difficult, there exist in practice contractual and institutional instruments with the same effects i.e. control. Those instruments of control may be of different types, such as the contract of management lease of activities conferring to one or several creditors of a company the control of management and resources

\footnotetext{
${ }^{7}$ Cass. crim, 27 juin 1972, n 72-91. 608. G 1973, II, n 17,335.

${ }^{8}$ Cass. crim, 22 juin 1999, n ${ }^{\circ}$ 98-13. 611. bull. Joly 1999, p. 978.

${ }^{9}$ CA. Douai, ch. 02 SECT. 02, 19 sept. 2012, n ${ }^{\circ}$ 07/01,415.

${ }^{10}$ Cass. com. $n^{\circ}$ 2-13,449 du 10 déc. 2003.

${ }^{11}$ The enterprise and the company are two things that are mainly distinct. The former is an economic and human organization. It is not a legal notion, but an economic and social notion, the second being a legal notion to serve the former, permitting to make the enterprise reach the legal life and its organizations (Paillusseau, 1984).
} 
of that company whereas there is not even the transfer of shares or of assets that has been effected. In addition, the contract of distribution may be susceptible of conferring to its holder the determining influence of the head of the group on the adherent (Hmoda, 2013).

The foregoing definitions and hallmarks of a corporate group induces one to turn up with a comprehensive definition of the corporate group and, as noted by (Pariente, 1999), this definition should be as large as possible with hope that it would cross several centuries. Thus, it may be considered to be a corporate group any economic entity bringing together two or several companies which enjoy their own separate legal entities, have their common interest superseding the particular interest of each and are subjected to the control of a single parent company head of the group. That control concretizes itself in the power of decision making within the subsidiary, due to the holding of a part of the share capital or rights of vote of this one, the power of appointment of the majority of its corporate organs and thus any other instrument producing the same effects.

\section{Corporate Group Structuring}

The structuring of corporate groups depends on how the parent company (ultimate holder) will exert the control over other member companies of the corporate group. In this instance, corporate group structuring hinges on the direct or indirect control by the parent company.

In this respect, Lecourt has identified three structures of corporate groups, namely pyramidal structure (structure pyramidale), radial structure (structure radiale) and the circular structure (structure circulaire) (Lecourt, 2013). To these, (Desfeuillet, 2002) has added the complex structure.

The radial structure is more frequent in small enterprises made up of the parent company and several subsidiaries directly held by the former. The Pyramidal structure can be more frequently observed in large enterprises. In this structure, through its subsidiaries, the parent company on top of the corporate group indirectly holds financial links in its sub-subsidiaries. The circular structure which is relatively rare, implies a chain of financial links between companies of the same group. Moreover, large corporate groups can use extremely complex structure through combining the aforementioned three structures (Gauthier, 2002).

\section{Corporate Group: A Double Edged Sword}

The assertion that corporate groups have become an increased phenomenon if not a norm in the today's, why not many years back's, business world is less troubling to put. However, one can inquire about the driving force behind this increased practice in the corporate world, and if at all whether there are no short comings associated therewith. In any case, what is preached by various scholars is that corporate groups are double edged swords i.e. they present both advantages and disadvantages. This was noted, among other scholars, by (Magnus, 2011) for whom, the advantage associated with corporate groups are for the group whereas in most of cases disadvantages reach the third parties who might have dealt with the member companies of the group.

Beginning with advantages, the structure of organization of companies in corporate groups presents a number of advantages. One of scholars who noted this are Jason Harris and Anil Hargovan in their article entitled "Corporate Groups: The Intersection between Corporate and Tax Law". Citing Melvin Eisenberg, they put that numerous economic benefits can flow from the use of integrated corporate groups to conduct business activities. In this respect, they asserted that the range of economic and commercial benefits available from operating corporate group structures include (Jason \& Anil, 2010):

1) reducing commercial risk, or maximising potential financial return, by diversifying an enterprise's activities into various types of businesses, each operated by a separate group company;

2) taking advantage of commercial opportunities by forming subsidiaries for use in joint venture projects, without involving the rest of the enterprise;

3) helping to reduce transaction costs by streamlining systems and building economies of scale;

4) taking advantage of tax benefits by operating local group companies in various countries with favourable tax treatment;

5) attracting capital without losing overall corporate control by creating a separate subsidiary to conduct the business and allowing minority shareholders to invest in it;

6) lowering the risk of legal liability by confining high liability risks, including environmental and consumer liability, to particular group companies, with a view to isolating the remaining group assets from this potential liability; and 
7) providing better security for debt or project financing, for example, a separate group company may be formed to undertake a particular project and obtain additional finance by means of substantial charges over its own assets and undertaking.

The slight look at these advantages implies that the use of corporate groups is a sure if not the surest mean in today's business world where tax has become a concern of each and every business person and the role played by multinational companies in global environmental pollution is not mysterious [...] (Namballa, 2014) ${ }^{12}$.

However, the noise of advantages offered by use of corporate groups should in no way overshadow well established disadvantages associated with what has become a common occurrence in the business world. (Hu, 2010) in his Ph.D. thesis entitled Le groupe de sociétés en droit français et en droit chinois has recognized and enumerated challenges and risks posed by corporate groups as follow:

The economic and financial weight of the group may be abusively used in detriment of its commercial partners. Further, the operation of more or less powerful groups can greatly change the game of market competition and balance of interests of actors legally linked to each company member of the group such as its shareholders, employers, directors and creditors.

Equally, such centralized and strong power can strongly blur the distinct identity of its member companies. The sliding of power towards the top of the group may lead to the disequilibrium of relations between the group and the company belonging thereto. If theoretically, the company member of the group again remains legally distinct, this does not deprive the group of its power to influence the relations between that company and its participating parties. This influence of the group is mainly observed in three categories of individual relationship between the corporate group and the parties involved in the operation of each of the company member of the group. 1) It may happen that the shareholders of the company member of the group be divided into two clans: shareholders representing the group and those out of the group. The latter are excluded from the management of the group and there are only linked to the corporate interest of the concerned company, whereas the former are equally interested in the global interest of the group which may ultimately be opposed to the immediate interests of the company. The conflict of interests between majority and minority shareholders, an already traditional subject in company law, can be amplified in the context of corporate groups. 2) It may also happen that the employees of the company have the illusion that they are working not only for their own employer but also in the context of the group. The centralization of human resource management and the promotion of employees, the putting in place of intra-group mobility and the power to influence the group on the activities of the employer contributes to the reinforcement of that illusion. 3) Further, the co-contractors can chose to enter contracts with the company owing to the belonging of the latter to the group. In practices, material contracts are sometimes directly negotiated by the managing unity of the group prior to being executed by the company member of the group.

Besides, Magnus has done enormous work in putting forward the most serious (in one's modest position) disadvantage associated with corporate group. The disadvantage put forward by this legal scholar is clearly an advantage on part of the group, but very perilous to some of its stakeholders. He has averred that the decisions taken within the corporate group are based on preoccupations that are not comparable to those of isolated companies. Due to interdependence links that unite different companies, intragroup relationship is characterized by a solidarity that can in certain circumstances lead to the impoverishment of another company in the name of common wellbeing. Thus, when a company on which hinges the health of the group undergoes financial difficulties, it will seek assistance of other companies within the group for remedying such difficulties (for instance through loans without interests, assignment of loans, sale of goods at lower prices and transfer of employees). Although those behaviors of altruistic appearance are generally economically justified under the pretext of the existence or the survival of the group, these present the disadvantage of potentially adversely affecting the parties whose interests are only linked to the impoverished company. This brings about conflicts of interests between the group (which seeks to benefit from aids consented by the impoverished company) and stakeholders of the impoverished company (who have to bear the decrease of the consistency of that company in favor of companies in which they are not directly involved) (Magnus, 2011).

\section{Legal Nature of Corporate Groups}

The legal nature of corporate groups constitutes a controversial point in law and in this regard one may inquire

\footnotetext{
${ }^{12}$ In an attempt to cut costs, many multinational corporations (MNCs) export their polluting activities through subsidiaries established in less developed countries.
} 
whether it exists in law at all. Recalling the words of Pierre Estrabaud "the notion of corporate group is a prism that reflect a different image according to the branch of law in which it is being observed", from these words, one may put that there is no commonly acceptable legal nature ascribed to the corporate group and save for specific areas of law such as anti-trust (competition) law, tax law, labor law and accountancy law that recognizes economic realities surrounding corporate groups (Bouchard, 1997). Furthermore, several authors have quasi unanimously argued that the corporate group does not exist in law owing to its lack of separate legal entity.

For (Mbala, 2004-2005), the corporate group is a body of autonomous structures, subjected, due to the exercise of control or by will of collaboration, to the unity of direction in pursuance of the common object. The group of companies appears to be the system whose engine is the search of the effect of synergy, doubled by the emulation of different structures tending to satisfy the interests of each and every entity. As opposed to the company members of the corporate group, the corporate group does not possess the separate legal entity. The lack of legal personality by corporate group was equally underpinned by the writings of Charlaine Bouchard who put that by virtue of great principles of corporate law, the corporate group does not as such have the legal existence ${ }^{13}$. The same was also confirmed by the Court of Appeal of Paris where it held that the group of company is not the subject of rights vis-à-vis third parties ${ }^{14}$.

From these scholarly legal writings, viewed in ordinary law (droit commun) point of view, the corporate group does not legally exist as such. However as rightly noted by Charlaine Bouchard, some areas of law recognizes realities posed by the use of corporate groups. In this respect, (Hu, 2010) has asserted that areas such as competition law and accountancy law recognize the realities posed by corporate groups and thus consider them to be existent in the eyes of the law. In this respect, he put that French accountancy law provides for the establishment of, for certain group of companies, global annual accounts of the group resulting from the consolidation of accounts of company members of the corporate group.

This is also the case under the laws of Rwanda. For instance article 255 of the Companies Act ${ }^{15}$ provides that "the Board of Directors of a company that has one or more subsidiaries, shall, ensure that, within six (6) months after the financial year, a consolidated balance sheet is prepared. Such a consolidated financial statement shall be signed by at least one of the parent company's shareholders". Thus, for accounting purposes, corporate group exist under the laws of Rwanda. Hu has equally asserted that corporate group are recognized as existent in competition law. In this respect, he put that competition law takes into consideration the existence of corporate group, especially with regard to the acts in concert between member companies and pre-merger acts giving rise to the formation or expansion of the corporate group. This is also the case under Rwandan jurisdiction, and the relationship existing within corporate groups, beyond separate legal entity of each member of the group is recognized and the same have got the special treatment in anti-trust laws. For instance article 7 of the Competition Act ${ }^{16}$, excludes the prohibition of practices that are otherwise prohibited, when the same are undertaken within a corporate group ${ }^{17}$.

The realities imposed by corporate groups are also recognized in other areas of law such as tax law and employment law. For instance under Rwandan jurisdiction, company members of the same corporate groups are considered to be a related entity and the transactions undertaken between them are considered to be controlled transactions ${ }^{18}$. Equally, the realities imposed by corporate groups in employment has brought attention of various courts and the notion of co-employment according to which an employee of a subsidiary can be considered to be employed by the parent company or the fellow subsidiary as well was adopted. For instance, la Cour de Cassation of France (Labour Chamber) in its ruling of 9 June 2015 has held that the company member of the group may be considered to be co-employer towards the person employed by another only when there exist between them the state of economic dominance and that belonging can engender mixture of interests, activities and

\footnotetext{
${ }^{13}$ Charlaine Bouchard, Supra note 29, at 39 .

${ }^{14}$ CA Paris, 7 mars 1987, D. 1988.

${ }^{15} \mathrm{Law}^{\circ}{ }^{\circ}$ 07/2009 du 27/04/2009 relating to companies as modified and complemented to date, $O G, \mathrm{n}^{\circ} 17$ bis, 27/04/2009 (hereinafter referred to as Companies’ Act), art. 255.

${ }^{16} \mathrm{Law} \mathrm{N}^{\circ} 36 / 2012$ du 21/09/2012 relating to competition and consumer protection, in O.G. $\mathrm{N}^{\circ}$ of 12/11/2012.

${ }^{17}$ “... However, provisions of this Article shall not apply to enterprises dealing with each other in the context of a common entity wherein they are under common control or where they are otherwise not able to act independently of each other".

${ }^{18}$ The following companies are considered to be related: “a company and any person who owns directly or indirectly fifty per cent (50\%) or more, by value or by number, of the shares or voting rights in that company or two or more companies, if a third party owns directly or indirectly at least fifty per cent (50\%) or more, by value or by number, of the shares or voting rights in each company". See the Law $n^{\circ}$ 16/2005 of 18/08/2005 2005 on direct taxes on income as modified and complemented to date (hereinafter referred to as "Income Tax Act") article 2 .
} 
direction that manifests itself through the immersion of one of the companies in economic and human resource management of another company ${ }^{19}$. Furthermore, Rwandan courts have also established two tests that would allow to look beyond legal entities of each group members and condemn more than one member for employment obligations arising from the contract entered into with one entity (co-employment). In this respect, the Intermediate Court (IC) of Nyarugenge has for the first time and recently held that two related entities (members of the same corporate group) may be found to be co-employers when there exist the subordination link (even if there is no contract of employment) between the employee and the alleged co-employing company and interference of the later in the activities and management of another company (direct employer) ${ }^{20}$.

This view of the Cour de Cassation Francaise (Labour Chamber) and the Intermediate Court of Nyarugenge are very important, since as noted by (Bertrand, 2013), within corporate groups key staffs of subsidiaries are appointed at the level of the parent company and transfer of employees among company members of the group has become a monotonous.

From the foregoing one asserts that groups of companies have gained a controversial treatment. On one side, the legislators have shown their position of persisting reticence, by constantly refusing the slight legal identity of corporate groups and on the other side, the corporate groups are frequently recognized by the legislators and practitioners of various branches of law in the area of commerce and economy, at the same time becoming an unavoidable contour in the application of the law.

\section{The Intra-Group Relationships (the Life of a Corporate Group) and Their Legal Implications}

The nature of a corporate group as averred by (Robé, 1999) that the technique of corporate group allows to bring together in a single organization, in a single and same enterprise, various activities organized around each of the companies of the group, understandably creates certain relationship that cannot be easily, if at all, observed on unrelated/isolated companies.

This special nature of intra-group relationship has been clearly described by (Magnus, 2011) who qualified it to be akin to a family relationship. He said in his French words, "l'articulation des relations au sein du groupe peut être comparée à une organisation familiale de type matriarcal, composée d'une pluralité de personnes dotées d'un patrimoine propre ainsi que d'une indépendance juridique, dont l'autonomie est limitée par le contrôle exercé par une 'mater familias' (la société mère) qui surveille et coordonne les agissements dans l'intérêt familial, et au sein de laquelle certaines opérations peuvent être réalisées à des conditions plus avantageuses qu'entre étrangers (telles que des donations ou des aides financières)" ${ }^{21}$.

In this respect, the doctrine has emerged with three types of relationship that can be observed in most if not all corporate groups and those are intra-group dealing/trading, intra-group lending and intra-group guarantee.

\subsection{Intra-Group Dealing/Trading}

Intra-group trading/dealing involve the transfers of goods and services, capital (such as money) and intangibles (such as intellectual property) within a corporate group, and such transfers are called "intra-group" transactions or otherwise controlled transactions (Robert, Charles, \& Richard, 2008) or related parties transactions. There is evidence that intra-group trade is growing steadily and arguably accounts for a significant part of all international transactions (Sandslatt, 2008). The structure of transactions within a corporate group (the com-ponent parts of which, such as companies, are also called "associated enterprises" in the language of intra-group transaction) is determined by a combination of the market and group driven forces which can differ from the open market conditions operating between independent entities (Danny, 2011). Thus, a large and growing number of intra-group transactions are not governed entirely by market forces, but by forces which are driven by the common interests of the entities of a group (United Nations, 2013). The prices set in intra-group transactions can be lower or higher than they would have been should the transfer have been undertaken between independent entities (on arms' length basis), and the technique of setting prices in intra-group transaction is called "transfer pricing" (Maurício,

\footnotetext{
${ }^{19}$ Cass., Soc., 9 June 2015, 13-26558.

${ }^{20}$ IC Nyarugenge, 23/02/2015, Judgment No RSOC 0305/14/TGI/NYGE.

${ }^{21}$ Roughly translated the articulation of relationships within the corporate group can be compared to a family organization of a matriarchal nature, composed of several persons with their own patrimony ad their own legal independence whose autonomy is limited by the control exercised by "the mater familias" (parent company) which oversees/coordinates the activities within the family interest and within which certain activities can be undertaken on more advantageous conditions than between unrelated parties (such as donations and financial aids).
} 
2013).

The main purpose of transfer pricing involved in intra-group/controlled transactions (albeit there are other ends) is mainly the shift of profits in low or non-tax jurisdictions. In this respect, (Gravelle, 2015) has elaborated on how transfer pricing driven by profit shifting works. In this respect, he put that firms charge low prices for sales to low-tax jurisdictions affiliates but pay high prices for purchases from them.

The fact that transfer pricing is being used by Multinational Corporations in shifting their profits in low or non-tax jurisdictions has brought the attention of legislators in various jurisdictions and thus the arms' length principle was adopted. The arms' length principle was recommended by OECD (Organization for Economic Cooperation and Development) in its Model Tax Convention on Income and Capital which has framed the same principle as follow: "Conditions are made or imposed between the two enterprises in their commercial or financial relations which differ from those which would be made between independent enterprises, then any profits which would, but for those conditions, have accrued to one of the enterprises, but, by reason of those conditions, have not so accrued, may be included in the profits of that enterprise and taxed accordingly"22. This principle has been adopted in Income Tax Acts of various jurisdictions, Rwanda inclusive. Under the laws of Rwanda the OECD arms' length principle is almost verbatim provided under article 30 of Income Tax Act which states,

"Where conditions are made or imposed between related persons carrying out business in their commercial or financial relations which differ from those which would be made between independent persons, the Commissioner General, in accordance with regulations issued by the Minister, may direct that the income of one or more of those related persons is to include profits which he/she or they would have made if he/she or they operated as independent persons".

The arms' length principle as enshrined under the Income Tax Act constitutes an important tool to curb the tax avoidance by large multinational corporations through transfer pricing, since as noted above a large and growing number of intra-group transactions are not governed entirely by market forces, but by forces which are driven by the common interests of the entities of a group and this may erode the tax base and shift profits of and/or from some countries (especially those with high tax jurisdiction).

Nevertheless, although the taxman (by establishing the arm's length principle) has curbed possible tax avoidance through transfer pricing, the protection of creditors of members of corporate groups is still hanging, since transfer pricing may be used to impoverish one group member in detriment of another, by shifting assets of one company to another on artificially low prices. Neither Rwandan legislator nor courts have given relief for creditors of the impoverished members of the group. However, other jurisdictions have provided such a relief. For instance the Cour de Cassation of France has held that the existence of transaction entered among members of the group not on arm's length basis (financial flow without or with artificially low compensation) constitute commingling of assets and the later would lead to considering the whole group as a single entity and thus the possibility of holding one entity for the debts of another ${ }^{23}$.

\subsection{Intra-Group Lending}

Within corporate groups, it is not strange to find that some member companies of the group are highly leveraged (thin capitalized). A company is said to be thin capitalized or highly leveraged when it is more debt financed than it is equity financed (X, 2015). The thin capitalization of companies within the same group has more implication than the thin capitalization of isolated companies, since the thin capitalization of companies within the corporate group arise from the intra group lending and this has become an increased practice of corporate groups, as the same is used as a form of shifting profits within corporate groups, given that interests paid on loans are generally deductible from taxable corporate income. When a group member company is debt financed through loans from another group member company, since the interests are generally deducted from taxable corporate income, it decreases its tax burden while the interests are paid to a related entity and therefore taken into the pockets of the same ultimate holder. In this respect, (Blouin et al., 2014) have argued: "multinationals can reduce their worldwide tax incidence by concentrating their debt in relatively high-tax countries. Hence, the leverage of a multinational firm is particularly sensitive to a jurisdiction's tax rate, and tax authorities face declining corporate tax receipts from multinational firms that use excessively high leverage and concomitant interest

\footnotetext{
${ }^{22}$ See article 9 of Model Tax Convention on Income and Capital, OECD Committee on Fiscal Affairs, 1992, updated as of $1^{\text {st }}$ September 1995.

${ }^{23}$ Cass. 1ère ch. civ., 5 juill 1989, Rev. soc. 1990. Somm. 76, Bull. civ. I, n² 272, p. 181.
} 


\section{deductions".}

However, the thin capitalization of companies is strictly regulated when it comes to corporate groups and various jurisdictions have adopted thin capitalization rules that restrict interest deductibility if the debt ratio exceeds a certain limit. For instance, in Rwanda, the legislator has taken into account profit shifting due to intra group lending and adopted tight thin capitalization rules. In this respect, article 22 of the Income Tax Act provides, "In the case of a taxpayer other than an individual, interest paid on loans and advances from related entities is not deductible to the extent that the total amount of the loans and/or advances in respect of which the interest is paid exceeds four (4) times the amount of equity, during the tax period".

Nevertheless, the fact that Rwandan legislator has put in place thin capitalization rules applicable to intragroup lending is not sufficient to curb tax avoidance arising there from. In this regard, it is worth noting that while there is a clear debt equity ratio, corporate groups may still have a room to avoid taxes through lending their relatives in Rwanda on high interests, without being limited by thin capitalization rules under article 22 of the Income Tax Act.

\subsection{Intra-Group Guarantee}

Prior to discussing the intra group guarantee the relevancy of guarantee as noted by (Andrew et al., 2002), is worth to mention. They put that in complex international leveraged transactions crossing many borders, guarantees, along with other credit enhancement devices, such as indemnities, bonds, keep well agreements, comfort letters, liability purchase agreements and standby letters of credit, are widely used as a form of security. However, out of all of these devices, it is the guarantee which has the mass appeal. Under a guarantee, the guarantor enters into a contract by which it agrees to be liable for the present and future obligations of a principal to a creditor, usually a lender. The liability of the guarantor is in addition to, and not instead of, the obligation of the principal. This makes them extremely popular to lenders (Andrew et al., 2002).

The mass appeal to guarantee has not discriminated against companies, but instead the same practice can be witnessed in the corporate world and more significantly in corporate groups, since as noted by (Squire, 2011), "When a business firm gets big enough, it reliably does two things. First, it reconfigures itself into a corporate group by dividing itself into a multitude of commonly owned subsidiaries. Second, it causes the various entities in this group to guarantee each other's major outside debts". Intra group corporate guarantee can be of three categories namely upstream, downstream and cross stream. The upstream guarantee comes in when the subsidiary guarantees the borrowing of the parent company, the downstream guarantee comes in when the parent company guarantees the borrowing of its subsidiary and the cross-stream arises when the subsidiary guarantees the borrowing of another subsidiary/ies with which they belong to the same corporate group (Graham, 2006).

The Rwandan legislator does not explicitly provides for the possibility of having the parent company guaranteeing the obligations of its subsidiaries nor the subsidiaries guaranteeing obligations of their sister companies. However, article 208 of the Companies Act explicitly permits subsidiaries to guarantees loans issued to their parent companies (upstream guarantee). However, in spite of the fact that the Companies' Act does not explicitly permits parent companies to guarantee loans issued to their subsidiaries or the latter to guarantee loans issued to their sister companies (cross-stream), one submits that as long as they have been subject to proper corporate authorization and meet the "best interest of the company test" such a downstream guarantee would be valid and enforceable (Andrew et al., 2002).

Nevertheless, intra group guarantee presents itself to be disadvantageous on part of some creditors, since the heavy use of the intragroup guarantee causes the creditors of one group member to bear the risk that another member will fall insolvent if the former has guaranteed the borrowing of the latter.

Although it has been argued that creditors who anticipate that their bankruptcy recoveries will be diluted by intragroup guarantees can try to protect themselves by contract, by for instance demanding higher interest rates up front to offset the losses they expect to incur if the guarantees are triggered (Squire, 2011), the excessive use of intragroup guarantees may create the intricate web of cross, up and downstream guarantees. In this case, the judge will arguably resort to substantive consolidation where all group members are considered to be a single entity and all assets and liabilities of the group are consolidated into one pool (Jin, 2015). However, the very nature of the substantive consolidation (negation of the corporate boundaries) makes it extra-ordinary and it must be used sparingly (Jin, 2015), and this is hardly achievable when some members of the group are offshore, as insolvency laws are national in scope. 


\section{Conclusion and Recommendations}

The legal regime of corporate groups has brought attention of various scholars. However, it is beyond any discussion that the use of corporate groups is an entrenched feature of the modern commercial world, where various companies enjoying their own legal personalities share common interests superseding particular interests of each among them and being under control of one of all of them, parent company. The use of corporate groups is justified by various ends such as reducing commercial risk, or maximizing potential financial return, by diversifying an enterprise's activities into various types of businesses, each operated by a separate group company and taking advantage of tax benefits by operating local group companies in various countries with favorable tax treatment. Corporate groups have got various structures and some are organized in a complex manner akin to spider' web and such structuring and the modus operandi of this economic and commercial reality creates a number of issues and seem to adversely affect participating parties such as employees, creditors and minority shareholders without forgetting tax administration and regulatory bodies. Despite the consensus that multi-tiered corporate group structures dominate national and world's economy and the same have been used for uncommendable ends, they, in law, remain to be unregulated as such. However, there is a sectorial approach whereby corporate groups are recognized by various areas of laws such as tax law, insurance and banking, competition and employment each of which having its own conception of corporate groups.

However, the lack of general legal approach towards corporate groups compels one to put forward various recommendations both to the legislator and the corporate world. Regarding the legislator, it is worth to note that corporate groups are one of the areas that have remained unregulated for a considerable period of time while it is an evitable and even increased reality in business world, Rwanda not being spared. Thus, a need to enact laws or at least legal provisions determining the legal nature of corporate groups and indeed leaving room for interpretation by courts of law give a kind of guidance regarding handling various issues arising from corporate groups. As for the corporate world, although corporate groups have become a surest mean to reduce commercial risks and maximizing potential financial returns, they need to be cautious in intra-group operations, as albeit the lack of a general legal approach towards corporate groups, dissecting legal approach such as thin capitalization and transfer pricing rules, and the doctrine of single entity or alter ego (in some jurisdictions) adopted by courts are in some instances relied to in handling some scandalous behaviors observed within corporate groups, and thus in all operations observe the arm's length principle and the legal entity of each group member by avoiding to interfere with their management save in exercising their ordinary shareholder's control.

\section{References}

Andrew, P., Richard, J. T., Marc, S., Gary, G., Joseph, S., \& Coq, V. (2002). The Economic and Commercial Benefits of Corporate Guarantee: An International Comparison. Butterworths Journal of International Banking and Financial Law, 259-263.

Barthelemy, M., \& Philippe, J. (1996). Companies. Editions Francis Lefebvre.

Bertrand, L. (2013). The Liability of Parents Companies Vis-à-Vis Their Subsidiaries in Labour Law. Paris: Panthéon-Assas Paris II University.

Blouin, J., Huizinga, H., Laeven, L., \& Nicodème, G. (2014). Thin Capitalization Rules and Corporate Leverage. http://www.voxeu.org/article/thin-capitalisation-rules-and-corporate-leverage

Blumberg, P. (2005). The Transformation of Modern Corporation Law: The Law of Corporate Groups. Connectcut Law Review, 605.

Bouchard, C. (1997). The Legal Personality Demystified: Contribution to the Definition of the Legal Nature of Companies of Quebecois Persons. Saint Foy: Laval University Press.

Danny, O. (2011). Global Transfer Pricing Trends. International Transfer Pricing Journal, 119.

Desfeuillet, M. (2002). Corporate Groups Confronted to the Theory of Abnormal Acts of Management. Robert Schuman University.

Dickfos, J. (2011). Enterprise Liability for Corporate Groups: A More Efficient Outcome for Creditors. Australian Journal of Corporate Law, 25, 242-273.

Didier, P. (1996). Commercial Law. RIDC, 222-513.

Duet, A. C. (2007a). Being or Not Being: The Group as a Unified Enterprise or a Body of Companies? A Sociological Approach. Law and Companies, 615. https://www.cairn.info/revue-droit-et-societe-2007-3-page-615.htm

Duet, A. C. (2007b). The Governance of Corporate Groups, Relationships between Property and Power to the Test of Rela- 
tions of Contemporary Enterprise. Université de Pierre Mendes France-Grenoble II.

Estrabaud, P. (2014). Corporate Groups in Anti-Trust Law and Tax Law. Paris: Pantheon Assas, Paris II University.

European Commission (2015). Commission Decides Selective Tax Advantages for Fiat in Luxembourg and Starbucks in the Netherlands Are Illegal under EU State Aid Rules. Brussels: European Commission.

Gauthier, T. (2002). Directors and Corporate Groups. Litec.

George, R., René, R., \& Germain, M. (1993). The Traitize of Commercial Law. L.G.D.J., nº 1608.

Graham, D. V. (2006). Project Finance. London: Sweet \& Maxwell.

Gravelle, J. G. (2015). Tax Havens: International Tax Avoidance and Evasion. Congressional Research Service.

Hmoda, F. (2013). The Protection of Creditors within Corporate Groups. University of Franche-Comte.

Hu, X. (2010). Corporate Groups under French and Chinese Law. Université of Angers.

Jason, H., \& Anil, H. (2010). Corporate Groups: The Intersection between Corporate and Tax Law, Commissioner of Taxation v BHP Billiton Finance Ltd. Sydney Law Review, 723-738.

Jin, K.-Y. (2015). How to Eat an Elephant: Corporate Group Structure of Systematically Financial Institutions, Orderly Liquidation Authority and Single Point of Entry Resolution. The Yale Law Journal, 1241.

Lecourt, A. (2013). Corporate Groups, in Repertoire of Company Law. Paris: Dalloz.

Magnus, F. (2011). Corporate Groups and Protection of Categorial Interests. Larcier.

Maurício, M. J. (2013). Transfer Pricing and the Arm's Length Principle in the European Union Law and Domestic Law. Braga: Universidade do Minho.

Mbala, M. (2004-2005). Intra-Corporate Groups Agreements. Lille: University of Law and Health-Lille.

Merle, P. (2005). Commercial Law: Companies (10ème éd ed.). Paris: Dalloz.

Mevorach, I. (2009). Insolvency within Multination Enterprise Group. Oxford: Oxford University Press. http://dx.doi.org/10.1093/acprof:oso/9780199544721.001.0001

Namballa, V. C. (2014). Global Environmental Liability: Multinational Corporations under Scrutiny. Warwick Research Journal, 1. http://exchanges.warwick.ac.uk/index.php/exchanges/article/view/26/100

Paillusseau, J. (1984). Foundations of Modern Company Law. JCPE, 263.

Pariente, M. (1999). Shareholders of Companies Linked to the Corporate Group. Soc. Rev., 468.

Robé, J.-P. (1999). The Enterprise and the Law. Paris: PUF.

Robert, J. P., Charles, H. G., \& Richard, C. P. (2008). International Income Taxation. CHH.

Sandslatt, P. P. (2008). Transfer Pricing: The Global Divergence Regarding the Documentation Requirements. Gutenberg: University of Gutenberg.

Squire, R. (2011). Strategic Liability in the Corporate Group. University of Chicago Law Review, 78, 605-669.

United Nations (2013). United Nations Practical Manual on Transfer Pricing for Developing Countries. New York: United Nations.

Vidal, D. (1993). The Foundations of Punctual Methodology of the Law of Corporate Groups. LPA, 17.

X. (2015, 12 30). Moneyterms. http://moneyterms.co.uk/thin-capitalisation/ 